Studia Anglica Posnaniensia 50/2-3, 2015

doi: $10.1515 /$ stap-2015-0025

\title{
THE CONCEPT OF THE SELF IN COME WALK WITH ME: A MEMOIR BY BEATRICE MOSIONIER
}

\author{
AGNIESZKA RZEPA \\ Faculty of English, Adam Mickiewicz University in Poznań
}

\begin{abstract}
Beatrice (Culleton) Mosionier is a Canadian Métis writer, whose first strongly autobiographical novel In Search of April Raintree (1983) has been recognized as a classic of contemporary Native Canadian literatures. Her memoir, Come Walk with Me (2009), describes her life story from 1949 till 1987, covering also the period between 1987 and 2001 in a brief epilogue. In the memoir, Mosionier uses fragments of the transcript of an interview conducted with her mother in 1984 by Alanis Obomsawin to preface the three parts of her book. Apart from constructing the two lives as parallel and in dialogue with one another, Mosionier frames and dialogises her story also through references to the process of writing, publication and the success of her novel; and reaches out to readers to induce them to "walk" with her. The aim of the present article is to examine the narrative presentation of the process of self-discovery focusing in particular on the relational aspects of the life story. Mosionier's memoir demonstrates her growing into the realisation of the fact that her identity is relational — she recognizes herself as part of a larger ethnic and social group, and later also as shaped by familial relations. While depicting "the self [that] is dynamic, changing, and plural" (Eakin 1999: 98), she conceptualises it in reference to what she believes to be an essentially static core identity, and as "channelled" through a life that largely follows a predetermined pattern.
\end{abstract}

Keywords: Native Canadian autobiography, relationality, Beatrice Mosionier, Métis autobiography, life writing

\section{Preliminaries}

Beatrice (Culleton) Mosionier is a Canadian Métis writer, whose first strongly autobiographical novel In Search of April Raintree (1983) has been recognized as a classic of contemporary Native Canadian literatures. Her memoir, Come Walk with Me (2009) is based on the familiar "life is a journey" metaphor and 
describes the autobiographical narrator's life as anchored in the pivotal moment of epiphanic self-discovery. While not as popular as the novel, it "made the 'Winnipeg Bestsellers' list upon its release, [and was] named the number one bestselling paperback non-fiction at McNally Robinson Booksellers" (Aboriginal Author 2009). While it has been relatively widely reviewed, mostly by Manitoba press, it has not as yet become the subject of an extended critical inquiry.

The memoir describes Mosionier's life story from 1949, when she was born, till 1987, when she makes two momentous decisions: one professional and one personal. She decides to withdraw from frantic publishing- and social-activism-related work she was drawn into in the wake of the success of her novel and to "work quietly behind the scenes" (Mosionier 2009: 169); and to leave her husband and move from Winnipeg to Toronto with her new partner and her children. The memoir finishes with a brief (ten pages long) epilogue covering the period between 1987 and 2001 and briefly talks about her satisfying domestic life, further publishing and social activity, and the old age and death of her parents. Mosionier prefaces the three parts of her memoir with fragments of the transcript of an interview conducted with her mother in 1984 by the well-known singer and documentary filmmaker Alanis Obomsawin. Apart from constructing the two lives as parallel and in dialogue with one another, she frames and dialogises her story also through references to the process of writing, publication and the success of her first novel; and reaches out to readers to induce them to "walk" with her.

The aim of this article is to examine the narrative presentation of the process of self-discovery focusing in particular on the relational aspects of the life story. While it has become a commonplace in life writing studies to state that all identity is relational, i.e. "developed collaboratively with others" (Eakin 1999: 69), it is not always conceptualised as such in life narratives. Mosionier's memoir demonstrates her growing into the realisation of the fact that her identity is relational-she recognizes herself as part of a larger ethnic and social group, and later also as shaped by familial relations. What is more, she demonstrates how she comes to accept a larger sense of self, often presented as typical of Native people and encapsulated in the phrase "all my relations," that embraces not simply the family and the community, but all creation, animate and inanimate, throughout time (Weaver 1997: 39). This broader sense of self follows clearly from the description of her understanding of Native spirituality, copied in the memoir from the novel (Mosionier 2009: 149), though not necessarily from other parts of the memoir. Interestingly, however, while depicting "the self [that] is dynamic, changing, and plural" (Eakin 1999: 98), she conceptualises it in reference to what she believes to be an essentially static core identity, and as "channelled" through a life that largely follows a predetermined pattern. 


\section{Social context: a sketch}

Beatrice Mosionier comes from a Catholic Métis family - a background whose importance she discovers only as an adult. The Métis in Canada have a history as long as the beginnings of the fur trade, and were and are a highly diversified group. As people of mixed, Native and European - often French - parentage, in the past they frequently followed a Native way of life; some became integrated into white communities. Importantly, however, there also developed a group of the Métis people, inhabiting first the area of the Hudson Bay and later primarily the Red River area and the surrounding prairies, whose culture and life patterns (originally primarily nomadic) were unique, many of whom spoke either a Native language (often Cree) or Michif - the Métis language - and were practicing Catholics. This group, which had a strong sense of racial and cultural difference, in the 19th century actively resisted the territorial expansion of Canada into the west of the continent by organising armed rebellions, and instituting a provisional government under the leadership of Louis Riel. Today, many (though by no means all) Canadian Métis still see themselves as Métis Nation peoples (LaRocque 2010: 7; Episkenew 2009: 54-57), while for others the label indicates simply mixed heritage.

Since 1982 the Métis have been recognized in the Canadian constitution as one of three distinct aboriginal groups in Canada (the other two being Indians, i.e. First Nations people, and the Inuit), and they have always been recognized as distinct from the First Nations peoples, and labelled in the past "non-Indians". In consequence, because well into the 20th century there was no legislation addressing specifically this group, the Métis escaped some of the abuses of the government that the First Nations people suffered (for example, the majority could not and did not attend the infamous residential schools). At the same time, as a result of vague legislative regulations they were offered no assistance or rights available to First Nations, but suffered from the same racist attitudes and economic disadvantages. The result was, among others, rampant illiteracy, poverty (Episkenew 2009: 58-59) and the marginalisation of the Métis, who, not included in the category of "the other" inhabited by Indians, have functioned - in the words of Tricia Logan — as "the other other" (2008: 96). Also, as especially after WWII many Métis families moved to cities in search of work, some close-knit Métis communities were dispersed, leaving families without a safety net provided by extended family and community networks. It was in the 1960s that newly-established Métis organisations, like the Manitoba Métis Federation, started to promote a more positive self-image and Métis solidarity in order to counteract "negative identification" based on the sense of not belonging to any of the legally recognised ethnic categories (Smulders 2006: 77-78). Nevertheless, even today the category of the Métis remains broad and highly flexible. 
At the turn of the 1940s and 50s child care policies in Canada changed and, as much evidence indicates, started to be used as a tool of assimilation of the indigenous peoples (Episkenew 2009: 67; Alston-O'Connor 2010). Native, both First Nations and Métis, children were removed from their families, often without the knowledge and agreement of parents or caretakers, sometimes in response to parents' approaching child care agencies for help. The children were placed predominantly in white families in Canada and abroad as foster children and adoptees. The practice became widespread in time and it came to be known as "the Sixties scoop", though it had started earlier and continued through the 1980s. Some scholars believe the practice is still followed today (Episkenew 2009: 65). At the close of the 1960 s, "30 to 40 percent of all legal wards of the state in Canada were Aboriginal children, even though they formed less than 4 percent of the national population" (Fournier and Crey 1997: 83; as qtd. by Alston-O'Connor 2010). The result was the disruption of the family, personal suffering and deculturation, as well as the weakening of indigenous communities.

\section{The epiphany}

Mosionier's story hinges on the drama of her and her siblings being taken away in 1952 from their parents - because of parental negligence and alcoholism - and placed in white foster homes. It is therefore to a certain extent representative of the generation of "the Sixties scoop". Mosionier is separated from her birth family at three and till adulthood has only rare contact with her parents and siblings. For a long time, she blames the parents for what has happened to the family and for abandoning her, assuming that she was not wanted and loved. The family is never reunited, even though theoretically such a possibility exists as Beatrice is "a temporary ward" (Mosionier 2009: 31). She will remain in foster families till she is 15 and — on her own demand — starts attending a boarding school. Feeling trapped, "always waiting" for her parents to take her home (Mosionier 2009: 31), at 11 she decides not to attend family visits, during which her Mom no longer appears, and to emotionally renounce both her birth and foster family.

The story told in the memoir is one of Beatrice Mosionier growing into an understanding about "who I am" (Mosionier 2009: 134), as she puts it, but also of her growing into a deeper understanding of the reasons for her parents' actions and the plight of her family. The identity she discovers in October 1980, when she is 31 , in the wake of both her sisters' suicides, is her ethnic identity, whichafter a period of attempting to identify with the white people - she embraces with pride. She describes the epiphanic moment as follows:

The unconditional love I have for my children, and now Kathy [her sister], expands to include Vivian [the other sister], Eddie [her brother], my parents. I can love! And I do - and I suddenly know who I am. 


\footnotetext{
I am the one with special insight. I am the one who was given three guardian animals to guide me. I am Métis. Everything in my childhood, everything in my past has happened so I could come to this moment. I can wallow in self-pity or I can do the special thing that I was meant to do.

So what is that special something? It has to be figuring out the whys. (Mosionier 2009: 134-135)
}

The "whys" are related primarily to her family (the suicides of her sisters, the alcoholism of her parents), but also to the broader context that determines the fate of her family - the pervasive racism and discrimination of the aboriginal peoples in Canada. In order to get this deeper understanding she decides to write the autobiographical novel In Search of April Raintree. Describing the process, Mosionier reviews for the memoir reader the rationale for her narrative and thematic choices. She explains how the events from her life described in the memoir were generalised or turned into symbols in the novel and supplemented with what she knew other foster children experienced in order to demonstrate that the plight of her characters is really the plight of her people. The most powerful symbolic moment is perhaps the choice to describe in the novel in graphic detail her own devastating experience of rape and its aftermath-which are also described in the memoir. "The rape of April," she comments, echoing a metaphor very often used in texts by Canadian aboriginal writers, "is that of Native people worldwide, where dominant societies destroy a way of life through their oppression. (...) That is what forced assimilation feels like" (Mosionier 2009: 146).

The generalising metaphor has its roots in individual experience. The rape, as described in the memoir, marks Mosionier's private realisation that she is a victim of this crime not only because she is a woman, but specifically because she is an aboriginal woman stereotyped as "easy" or sexually available, which earlier allows white men to openly approach her for sex. During the rape she is also verbally abused and called, among others, a "squaw" (Mosionier 2009: 105). Therefore, while before the epiphany and writing the book she was not at all interested in social issues or the situation of the aboriginal people in Canada, now they become the focus of her attention. She notices, and reacts to, more and more instances of racist treatment that affect her and her children.

The writing of the novel is presented in the memoir as pivotal to the development of the autobiographical narrator, who almost until that moment attempts "to live like a white person" and accepts "the values of the dominant society" (Mosionier 2009: 145). The process of writing the novel marks both the realisation of and the maturing of Mosionier's relational identity: her growing into a person-incommunity, recognizing the mutual interactions and links between herself and this broader community contextualised historically and politically, and the validity of personal experience as part of communal experience. It also marks her growth into a writer, publisher and social activist: the spiritual growth is reflected 
in her actions and the way she lives her life. Even though the compulsion to organise experience through storytelling which connects the personal with the communal is presented in terms of an epiphany, it is in fact a consequence of the autobiographical narrator's long experience of abuse and systemic racism, her consistent development as a reader, the confidence that she can write instilled in her by a teacher, and her experience as member-at-large of the student council at George Brown College, where she for the first time takes a leadership role and speaks publicly.

\section{Identity formation process: subverting the Bildungsroman pattern / follow- ing a distinctly aboriginal trajectory}

Mosionier's memoir provides both an interesting example of contemporary uses of the genre of Bildungsroman as popular "templates for autobiographical storytelling" (Smith and Watson 2010: 91); and an example of what Kim Anderson (2000) has described as a process of identity formation characteristic specifically of Native women.

The text clearly follows the pattern of Bildung: it describes the autobiographical protagonist's education and the development of her consciousness thorough interaction with the society, and her growth to a recognition of her role within the society after the moment of the powerful epiphany. At the same time, the memoir demonstrates a new pattern common to contemporary novel and life-writing using the template: it challenges "the developmental narrative of assimilation, the different manifestations of 'normality,' and the genre's blindness to difference, shedding light on the violence hidden under what Moretti calls 'the comfort of civilisation" (Bolaki 2011: 13). Also, it aims at "disseminating claims to rights and registering conditions of right violations" (Smith and Watson 2010: 178). Mosionier presents herself as growing from the acceptance of social rules accompanied by attempts to "fit in" to a sense of social responsibility that involves rejecting some of those rules, thus changing the Bildung trajectory. Additionally, the "education" results in rejecting Roman Catholicism and embracing a noninstitutionalised - and rather vaguely described — understanding of spirituality that she sees as characteristic of Native people (Mosionier 2009: 148).

Her life journey, as described in the memoir, fits then also the four-steps selfdefinition schema identified by Kim Anderson on the basis of a series of interviews with aboriginal women (2000: 15-16). The process starts with resistance to a negative, imposed self-definition (related to the question "Who I am not?"), followed by reclamation of native traditions ("Where have I come from?"), and leads to the construction of "a positive identity by translating tradition into the contemporary context" ("What are my responsibilities?") and community-related action based on the newly-discovered positive identity ("Where am I going?"). 
Significantly, as indicated above, the autobiographical narrator assumes a new, relational concept of identity, coupled with a sense of social responsibility, which stands in contradiction to the identity emerging as a result of the traditional process of Bildung as it was worked out in Bildungsroman, i.e. essentially individualistic, separate though well-integrated into the society. This relational identity rests, as least partly, on what Anderson recognises as a "distinctly Aboriginal" sense that "the past, present, and future are (...) inextricably connected" (2010: 15) - hence Mosionier's focus on "the whys".

At the same time, even though she follows a dynamic trajectory of personal development, the autobiographical narrator's concept of self is that of an essentially static self, an internal "core" self that might be obscured or even forgotten for a while, but that is there if one knows how to get to it. Toward the end of the memoir, Mosionier's autobiographical narrator declares: "As a child, I knew I would do something special. I never thought I would become a writer. In rejecting my parents I rejected my heritage and buried the instincts of my childhood, but they would always be part of me. Today I am still the same person I was when I was three and realized I was alive" (2009: 185). She grows and changes, but she grows in her own perception into a discovery of who she has always been: the self embroiled in her extended ethnic community, the self with a mission. What is more, it is the self following a predetermined life pattern that was revealed to her as a "powerful instinctive feeling" when she was 13 , just as before she had suddenly understood that she had three guardian animals: "I'm going to give birth to a boy; five years after that I'll have a girl; I will never be married; and I'll die when I'm 81, but I'm never really going to die" (Mosionier 2009: 60).

The process of the unveiling of the relational self is signalled by the titles of the three parts of the memoir: "Walking alone"- "A Lonely Walk Home"- and finally the part which opens with the epiphanic experience titled "Come Walk With Me". Mosionier shows how, after her epiphany, she fosters the pride in her Native heritage. She also describes the process of her gaining a better understanding of the broader historical, social and contemporary cultural context by showing her interactions with the Native and non-Native people. She often recounts "learning/teaching moments" when she recognizes as racist the attitudes she used to take for granted, or when her uneducated perceptions are developed or corrected by people longer engaged in social activism and often also in (Native) publishing. Her growth as a Native person goes parallel to her growth as a writer and editor. These "moments" are also clearly introduced in order to illuminate the reader. A good example is her being corrected about the use of the term "Native" first by her brother Ed (Mosionier 2009: 151), because "that's the word the government uses for us", and then - more extensively and in detail—by Bernelda Wheeler, a host, producer and journalist: 
I ask her why this new term, "Aboriginal," is better than "Native." She explains that Aboriginal groups demanded the change, and it was incorporated in the 1983 amendment to the constitution Act of 1982. In the Indian Act of 1876, if you were "native," you weren't even a "person." I make the comment that the Métis aren't really Aboriginal people. With a mischievous grin, she says that's why Indian people call themselves the First Nations. (Mosionier 2009: 168)

Another example is her brief description of the discussion around the "appropriation of Native voice" (Mosionier 2009: 163-164), which was very important in Canada from the mid-1980s through the mid-1990s and involved not only writers, but also Canadians at large, because articles arguing a variety of positions in the discussion appeared in mainstream media, for example in The Globe and Mail, especially at the early stages of the discussion (see, for example Keeshig-Tobias 1990 or Lutz 2002a and Lutz 2002b). Taking the position of one who is trying to understand the concept and incorporate the principle in her professional practice, Mosionier spells out for herself, but also for the memoir reader, what the term means. As Mosionier's perceptions are being shaped, so are the readers'.

While after the epiphany the autobiographical narrator starts to proudly identify with the aboriginal people (cf. e.g. Mosionier 2009: 146-147), she never clarifies fully what it means to be a Métis. The category as such is never interrogated in detail by the autobiographical narrator. While the difference between First Nations people and the Métis is recognized, it does not seem to be significant as a discriminatory category of belonging, and seems to rest - though not always comfortably, as the quotation above suggests - within the broader category of "Nativeness" or aboriginality.

In this respect the memoir is not much different from the novel, in which, however, Métis identity dilemmas - in particular the potential "choice" or "split" between white and aboriginal identities - are discussed in more detail, and constitute one of the leading themes; though even the novel, to quote Janice Acoose, "does not successfully illustrate the Métis cultural identity" (1999: 228) and "does not create a Métis voice in the way that Métis nationalist writers (...) do" (1999: 229). In the novel Mosionier dramatizes the potential identitarian choice by splitting the quasi-autobiographical protagonist into two: the sisters who, while they look almost identical, have different skin-colour, which determines their early choices. Dark-complexioned Cheryl identifies as a proud Métis and a Native person adopting, however, "romantic stereotypes" of an aboriginal person; while light-complexioned April "is fed negative stereotypes" (Acoose 1999: 229) and attempts to lead a "white" life-style. It is the clash between the romantic stereotypes and the realities of Métis life in contemporary Canada that leads to Cheryl's suicide. April, on the other hand, faces consistent discrimination and oppression in spite of her attempts at fitting in. This, coupled with the rape April experiences, and the shock of her sister's tragic death, results in her eventual 
identification with the Métis and aboriginal people. The memoir seems to confirm that similar forces have been responsible for shaping the choices of Mosionier's autobiographical narrator. While first, unconsciously, she caves in under the pressure to assimilate, constant exclusion, discrimination, and denigration she and her family experience, lead her finally to proudly identify with the Native part of her heritage, in which she finds wisdom and beauty, but which she initially approaches as an outsider. This is how she recalls her "first powwow": "I know there's a reason for everything in Indian traditions but I can only watch as an outsider. (...) I am so proud of [the Native people]. I am so proud that part of me comes from them. This unexpected emotion, this reclaiming what I rejected, is what I need to give April” (Mosionier 2009: 146-147).

\section{Healing}

The novel and the memoir, published 16 years later, share the same aims: to show the reasons for the fate of the author and her family, which is treated in at least some aspects as representative of the fate of many aboriginal people in Canada; to demonstrate the racism they have to deal with; to validate the experience of others who have endured a similar fate; and to inform non-Native audiences about the reality of life of Native people in Canada. The aim is then in a very broad sense educational and therapeutic - to understand, to give witness, and therefore to heal - which allows the texts to be placed within the broad tradition of aboriginal autobiography in North America and beyond. Beatrice Mosionier, just like the character of April she creates for the novel, "is not exposed to the necessary influences for cultural transmission" (Acoose 1999: 229). Even though she has grown up without the context of Native storytelling, beliefs or spirituality-she has only intuitions and dreams that seem to connect her to that context and she has to educate herself about it as an adult (Mosionier 2009: 134-148) — her decision to write down her experiences is clearly related to what is sometimes described as the role of Native writers as contemporary storytellers. Fulfilling this role they fulfil the intertwining functions of the "healer, historian, medicine maker and prophet" (Armstrong 2006: 30) that have belonged to traditional tribal storytellers. The story, in particular an autobiographical story, gains a dialogical, relational dimension as it becomes a tool and medium of personal and, ideally, communal, even social and global healing and transformation (cf. Episkenew 2009: 15). The writer looks into the past, the present and the future to verbalise and validate the experience of the colonized forced out of the national myth created by European settlers, "to cure the settlers from the delusions learned from their mythology" (Episkenew 2009: 15). The aim is to heal themselves and the community through words by the narrativisation of trauma; to consolidate dis- 
persed communities by creating/strengthening the feeling of communal solidarity; and to give a vision of and hope for healing, and individual, social, and often global transformation. While Emma LaRocque cautions critics against making "healing" the exclusive measure of Native literatures, and imposing it as another utilitarian function they are required to serve (2009: 168), in the case of Mosionier's memoir healing is a professed aim of the text.

\section{Mother as the "proximate other"}

In the introduction to the memoir, which describes an episode in September 1984, a year and a half after the publication of the novel, Mosionier stresses the innermost of the widening circles described above: gaining personal understanding, filling in the gaps in her own story by describing it in the context of her mother's story, which she comes to know only late in life. She writes: "pieces of my life were missing and I needed to understand my mother's life. I had never asked Mom or Dad about their lives, for fear of making them relive painful memories" (Mosionier 2009: 2). Listening to the recording of the interview conducted with her mother by Alanis Obomsawin 18 years before, she recognizes that her mother's story intertwines with or runs parallel to her own, and can be viewed "as both a mirror to and context for [her] memories" (Mosionier 2009: 2). The mother functions here as, to use Paul John Eakin's term, "the proximate other", "the key other person" (1999: 86; Eakin's emphasis) in relation to whom the life of the autobiographical narrator is presented. As is often the case, the autobiographical telling is motivated by "the existence of tensions and secrets: there is a disruption, distortion, or omission in the family narrative that must be repaired" (Eakin 1999: 87), and more specifically by the absence of the parent. Mosionier concludes: "To a certain point, my life had been parallel to her life, almost as if we walked hand in hand. Then I let go of her hand to go my own way" (2009: 186). Prefacing the three parts of the book with fragments of the autobiographical narrative of Mary Clara Pelletier Mosionier, Beatrice's mother, is a central structuring and dialogising device within the text. Beatrice Mosionier's declaration, however, seems to contradict the life pattern implied by the titles of the three parts of the memoir or rather to suggest an inverted pattern: not from walking alone to walking together-from loneliness and separation to togetherness; but rather from walking alongside one another to walking alone, independently. The memoir shows then two seemingly divergent, but intimately interconnected "journeys" that the autobiographical narrator takes. She grows to "walk with" her mother because relatively late in life she becomes emotionally closer to her, recognizing that she did love her children and suffered when they were separated from her, and that at least part of her behaviour was socially determined. At the same time, Beatrice chooses a life path more and more divergent from the one her mother 
followed, as she becomes a sober, responsible parent and a socially engaged individual, consciously cultivating her links to family and community.

The way Mosionier makes the two texts- the transcript of the interview with the mother and her own memoir - speak to one another is through the simple device of placing them alongside one another. Having stated her aim in the introduction and having defined the mother's story "as both a mirror to and context for [her] memories" (Mosionier 2009: 2), she retreats from the role of the commentator or interpreter of the links between the stories, and assumes it again only in the closing paragraph of the epilogue which ends the memoir. The task of teasing out the connections is then the reader's, to whom the two life stories are presented in the same way in which the lives were lived: as separate from though parallel to one another. The task is not demanding: it is easy to notice the similarities - both women become wards of state at an early age; start working; meet their lovable but unreliable husbands early in life; remain in an on-again off-again relationship with them for a long time; have to fend for their children on their own for prolonged periods of time. What allows Beatrice to make her life-story diverge from the pattern her mother's story follows is that she shuns alcohol and finds internal resources that allow her to cope with the vicissitudes of life: personal problems, poverty, rape and racism. Her success is evidence of her personal qualities and strength of character, but also, in spite of all the social disadvantages she suffers from and systemic racism she encounters, a result of changing social realities, which include increasing aboriginal political and social activity, and higher institutional openness to the needs of the disadvantaged and minority groups.

There are two facts which are essential for the emergence of Beatrice's story as divergent from her mother's. One is that she does not lose her children to the state: against her expectations the Children's Aid Services do not take the kids away when she calls them because her husband leaves yet again, she has no means of support and suffers from post-partum depression. The other fact is her taking the essentially therapeutic and awareness-raising decision to write the novel in order to understand the fate of her family. Beatrice's and her mother's stories overlap only at times. The most important information that illuminates the reader's reception of both texts is the information the daughter does not for a very long time have and which relates to the mother's feelings about her children and her relations with them. For example, early on, at the end of the first part of the transcript, Mary Clara Mosionier describes her feelings after the children were taken away from her, saying: "Oh, my heart was torn into pieces" (Mosionier 2009: 8). Unlike young Beatrice, the reader knows from the very beginning both about the love and the suffering of her mother. Likewise, unlike young Beatrice, the reader knows that when the legal resources failed, the mother tried to illegally keep the son with her, that one of the older daughters escaped her foster family 
to live with the mother in hiding, and was again taken away from her; and that she spent longer periods of time with the two older daughters when they were adults. Unlike Beatrice, then, the older children did know, at least at times, their mother's whereabouts and possibly her feelings for them.

What the reader knows or suspects, comes as a revelation to the autobiographical narrator only late in her life, when she realises that her drama was also the drama of her parents. "I sit there quietly with tears in my eyes, remembering that I thought they had abandoned us and never did try to get us back. (...) I had never really forgiven Mom. Now listening to her anger and pain, I am filled with outrage by the racism they must have endured" (Mosionier 2009: 155), she writes. While in the wake of the suicide of her sisters she discovered that she can love, now she discovers that she was loved. Towards the end of the memoir, she credits her parents as the ones thanks to whom she was able to find inner resources to write the novel and survive, because they "have a childlike trust and innocence that had been passed to [her]" (Mosionier 2009: 169). Her parents, she concludes later, will always be "a part of [her]" (2009: 185). She finishes the memoir by returning to a fragment of the novel and connecting it with an experience she actually had: "In a scene from the novel, an Elder puts her hand on April's. As I wrote that scene I recalled having felt such a touch, one that was spiritual and full of warmth, compassion, and love. I know now it was my mother's hand" (Mosionier 2009: 186). It is in 2001, when she is 52, that Beatrice Mosionier recognizes an emotional and spiritual link with her mother that has eluded her almost throughout her life, and, in the memoir, recasts her life into an increasingly relational framework.

\section{Conclusions}

Mosionier's introduction to the memoir suggests that her intended audience is the same as the one for her novel - in fact, that it is the broad, Native and non-Native, audience that knows the novel and is familiar with the writer. This seems also to be the audience to which the memoir has been marketed. The publisher of both books - Portage \& Maine Press, which bought the rights to the novel in 1999states on its webpage and in the blurb on the back cover of the memoir that Come Walk With Me, somewhat belatedly, answers the question of the degree to which the novel In Search of April Raintree was based on the author's life (https://www.portageandmainpress.com/book_detail.cfm?biD=265). Mosionier does answer the question in the memoir, though much of the answer was known earlier through interviews and essays. In the process she involves the reader in the story of her further life and development. Sometimes, though rarely, she does that directly, by introducing questions she asks herself, but which might also be asked by the reader ("What makes me think I could write a book?"; Mosionier 
2009: 137) or phrases showing her awareness of the reading audience ("You know, like with the treaties"; Mosionier 2009: 181). She reaches out to her audience attempting to engage them in the text, to promote an active stance and a sense of companionship on the part of the reader: do not simply follow me, walk with me, which definitely is an invitation also to accept her social message andit might be presumed, but is not absolutely clear — might extend to taking a more activist stance in life. In the memoir, she attempts once again to educate and heal her readers, but also engages in the process of self-therapy. Additionally, as I have indicated, she places her life within a new framework, in a relation of dialogue with the newly discovered story of her mother's life, in effect strengthening the sense of her identity as relational. It is in this respect that she revises and develops views and perceptions one could find in the novel. Mosionier's memoir is constructed through a number of dialogical processes, positing a relational self coalescing around the "pivot" of what the autobiographical narrator perceives as her core identity and at least partially predetermined life story.

This article is part of the project on "The aesthetics and politics of the North American female memoir (1990-present)-multicultural perspectives" supported by the National Science Centre Poland under grant PRO2012/05/B/HS2/04004.

\section{REFERENCES}

2009. Aboriginal author of Canadian classic releases new title: Come walk with me, a memoir by Beatrice Mosionier. NationTalk, December 17. http://nationtalk.ca/story/aboriginalauthor-of-canadian-classic-releases-new-title-come-walk-with-me-a-memoir-by-beatrice-mosionier (accessed 10 May 2015.)

Acoose, Janice. 1999. The problem of 'searching' for April Raintree. In Beatrice Culleton Mosionier In search of April Raintree. Critical Edition, Cheryl Suzack (ed.), 227-236. Winnipeg: Portage \& Main Press.

Alston-O'Connor, Emily. 2010. The Sixties scoop: Implications for social workers and social work education. Critical Social Work: An Interdisciplinary Journal Dedicated to Social Justice 11(1). http://www1.uwindsor.ca/criticalsocialwork/the-sixties-scoop-implications-for-social-workers-and-social-work-education (accessed 09 May 2015.)

Anderson, Kim. 2000. A recognition of being: Reconstructing native womanhood. Toronto: Sumach Press.

Armstrong, Jeanette. 2006. Keynote address: The aesthetic qualities of aboriginal writing. Studies in Canadian Literature/Études en littérature canadienne 31(1). 20-30.

Bolaki, Stella. 2011. Unsettling the Bildungsroman: Reading contemporary ethnic American women's fiction. Amsterdam: Rodopi.

Eakin, Paul John. 1999. How our lives become stories: making selves. Ithaca and London: Cornell University Press. 
Episkenew, Jo-Ann. 2009. Taking back our spirits: Indigenous literature, public policy, and healing. Winnipeg: University of Manitoba Press

Fournier, Souzanne and Crey, Ernie. 1997. Stolen from our embrace: The abduction of First Nations children and the restoration of Aboriginal communities. Vancouver: Douglas \& McIntyre.

Keeshig-Tobias, Lenore. 1990. Stop stealing Native stories. Globe and Mail 26 January. A7.

LaRocque, Emma. 2010. When the Other is me. Native resistance discourse 1850-1990. Winnipeg: University of Manitoba Press.

Logan, Tricia. 2008. Métis scholarship in the $21^{\text {st }}$ century: life on the periphery. In Kerstin Knopf (ed.), Aboriginal Canada revisited, 88-99. Ottawa: University of Ottawa Press.

Lutz, Hartmut. 2002a. Cultural appropriation as a repression of peoples and histories. In Approaches: Essays in Native North American studies and literatures, 75-82. Augsburg: Wissner.

Lutz, Hartmut. 2002b. Confronting Cultural Imperialism: First Nations people are combating continued cultural theft. In Approaches: Essays in Native North American studies and literatures, 83-97. Augsburg: Wissner.

Mosionier, Beatrice Culleton. 1999. In search of April Raintree. Critical Edition. Ed. Cheryl Suzack. Winnipeg: Portage \& Main Press.

Mosionier, Beatrice. 2009. Come walk with me. A memoir. Winnipeg: Highwater Press.

Smith Sidonie and Julia Watson. 2010. Reading autobiography: A guide for interpreting life narratives. University of Minnesota Press.

Smulders, Sharon. 2006. "What is the proper word for people like you?": The question of Métis identity in In search of April Raintree. English Studies in Canada 32(4). 75-100.

Weaver, Jace. 1997. That the People might live: Native American literatures and Native American community. Oxford: New York. 